meteorites" available at the time. But the smaller grains (less than $100 \mu \mathrm{m}$ ) were inseparable from dust blown by the permanent wind, while 'cocoons' of bacterial material had grown around the larger grains. This made them difficult to study without damage and made analyses of their possible organic content meaningless. The only hope of finding intact micrometeorites was the Antarctic.

In 1988 Maurette and Pourchet set up their equipment in a polar caravan at Cap Prudhomme, $10 \mathrm{~km}$ from the Dumont d'Urville base.

Pourchet's 'factory' process involves injecting hot water into a small hole in carefully chosen blue ice (with no fractures), and pumping the water and melted ice back into a boiler. This cycle is repeated, gradually creating a pocket under the surface of the ice, about $1.5 \mathrm{~m}$ deep and $2 \mathrm{~m}$ long. At the end of the day the melted water is passed through a series of filters to trap the meteorites.

In the two available months of the Antarctic summer Maurette and Pourchet melted 100 tons of ice. And instead of the 500 or so grains they expected, they recovered 5,000 micrometeorites and about the same number of melted cosmic spherules. "About 3,000 of the micrometeorites turned out to be between 50 and $100 \mu \mathrm{m}$," says Maurette, the size range most abundant in the Earth's neighbourhood, leading him to believe they might be very well preserved. He attributes the unexpected success of the expedition to a 'superconcentrated layer' of ice between 20 $\mathrm{cm}$ and $1.5 \mathrm{~m}$ below the surface, where micrometeorites were far more common than at other depths. Analyses of the micrometeorites showed that they were even better preserved than those in Greenland and some still contained friable material.

For Maurette, some of their properties seemed to confirm that they were not fragments of meteorites. And they appeared unlike micrometeorites and interplanetary dust recovered from the stratosphere, suggesting that they may be more primitive. "So," says Maurette, "we have a new puzzle. Are these micrometeorites more primitive than the most primitive meteorites? We don't know. But we have a new population of material, it is very abundant and it is very primitive."

Maurette's current expedition to Antarctica with Michel Pourchet aims to collect new material, making sure "there is absolutely no contamination". Dust and particles of soot from diesel exhaust can look remarkably similar to some extraterrestrial material. But, ironically, the success of this expedition will add to his worries. He already does not know how to meet the increasing demand for micrometeorite samples from different laboratories. Each grain has to be analysed with a scanning electron microscope and then catalogued - a full-time job which he has been doing himself. But a solution seems to be at hand. Last year he helped launch EUROMET (see page 308) and was awarded a grant of FF630,000 over three years for a 'curator' for the collection. P.C.

\title{
Engineering feat or blight?
}

\section{Dumont d'Urville}

"REAlly, it is the only solution", says affable Michel Engler with a broad grin, as if he is used to speaking to people who are not convinced. Engler is director of Expéditions Polaires Françaises (EPF) and is in charge of engineering work on the FF100-million landing strip nearing construction at $\mathrm{Du}-$ mont d'Urville. A feat of engineering that has won reluctant applause from sceptics, the landing strip is to be the springboard for French Antarctic research into the next century.

But construction of the runway conflicts with concerns to protect the environment. As there is no ice-shelf to serve as a temporary runway - as at the US McMurdo base EPF engineers have had to blow up six islands, using the rubble to form a dyke. And these islands formed the only available nesting site for about 10,000 birds - notably Adélie penguins, Cape pigeons, snow petrels and Wilson's storm petrels.

At present, the only access to Dumont d'Urville is by sea. And until mid-December, a barrier of more than $300 \mathrm{~km}$ of ice makes it impossible for the modest class 1 icebreaker, Astrolabe, to reach the base. This restricts the summer research programme to

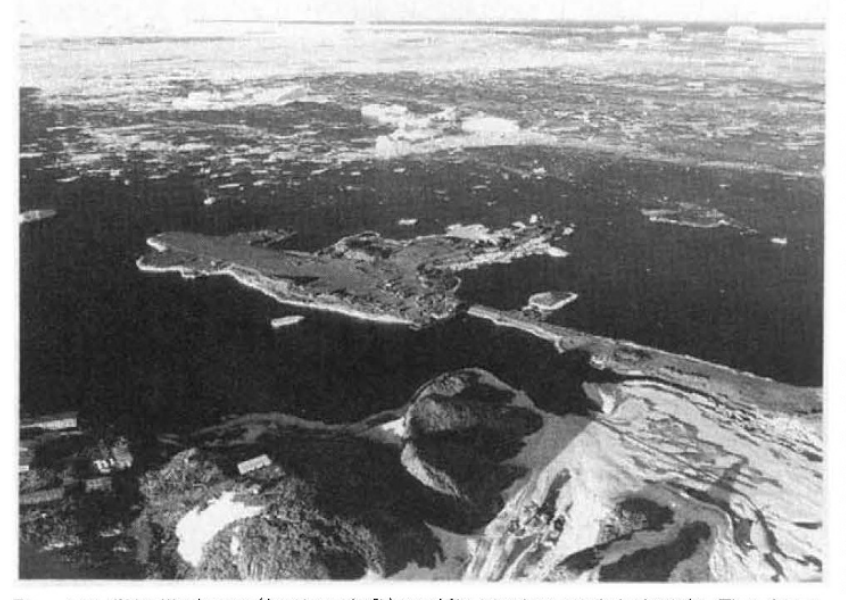

Dumont d'Urville base (bottom left) and its controversial airstrip. The Astro labe can be seen at its moorings (centre).

the months of January and February, whereas the weather is already good in October. And the feasibility of the proposed Dome $\mathrm{C}$ base rests entirely on researchers being able to arrive by air.

Extensive efforts are being made to limit the environmental impact of the airstrip. The TAAF, which has responsibility for the base, has earmarked FF4 million for detailed conservation measures - approved by the environment ministry and by the Scientific Committee on Antarctic Research (SCAR). As part of the arrangement, TAAF pays Vincent Bretagnolle, a biologist from the CNRS Centre for the Study of Wild Animals at Beauvoir-sur-Niort in western France, to supervise the protection measures.

Some problems have proved less intract- able than was feared. Greenpeace protestors tried to stop building work in 1988 , claiming that the strip cut across the preferred migration path of an important colony of Emperor penguins. Now, says Bretagnolle, two years of observations have shown that the Emperors will either walk around the dike or over it, using specially constructed gentle ramps and encouraged by lifelike dummies. And the 3,000 Adélie penguins reproducing on the destroyed islands have - against expectation - shown that they readily find nests nearby. Bretagnolle estimates that only two or three adult Adélies have been killed since 1984 , less than the daily meal of a sea leopard.

More at risk, he says, are the colonies of snow petrel and Cape pigeon. "These birds live for over 30 years. They take about eight years to find a mate and a nest, but keep both for life. If you destroy the nests, you destroy the colony." For these birds, all suitable nest sites in the archipelago were already taken. So Bretagnolle arranged for rocks to be broken on uncolonized islands, to create the right kind of crannies.

Although the emperor penguin colony has been less affected than was feared, says Bretagnolle, he fears that the worst is to come. "The emperors stampede when frightened", he says. Last May, 7,000 king penguins, mostly chicks, died on the Australian Macquarie Island when the colony stampeded, apprently because of a low-flying aircraft.

Michel Engler says it should not be possible for this to happen at Dumont d'Urville. The emperor colony has already returned to the sea at the height of the summer programme and (in theory) is not in the flight path.

"Now our biggest problem is finding the right plane for the runway", says Engler - a 'cart-before-the-horse' predicament that further fuels critics' accusations of poor planning. And no-one yet knows whether it is possible to predict weather conditions at the base with such accuracy that planes can take off from Hobart on the $6 \frac{1}{2}$-hour flight and be certain to be able to land. The biggest risk is from blizzards whipped up by sudden katabatic winds of up to $200 \mathrm{~km}$ an hour. So, this year, meteorologists from the national weather centre are installing sensors and building a model of the base for wind-tunnel tests. And there is one final worry, France has a poor ecology image in Australia and there is a slight risk that the powerful Green party in Tasmania might try to ban French flights. P.C. 